\title{
Has the World Cup become more migratory? A comparative history of foreign-born players in national football teams, c. 1930-2018
}

\author{
Gijs van Campenhout ${ }^{1 *}$ D, Jacco van Sterkenburg ${ }^{2}$ and Gijsbert Oonk
}

\author{
* Correspondence: \\ Vancampenhout@eshcc.eur.nl \\ 'Department of History, Erasmus \\ School of History, Culture and \\ Communication, Erasmus University \\ Rotterdam, Burgemeester Oudlaan \\ 50, 3062 PA Rotterdam, the \\ Netherlands \\ Full list of author information is \\ available at the end of the article
}

\begin{abstract}
While the presence of foreign-born footballers in national teams has a long history, it is often believed that the World Cup has become more migratory over time. The presumed increases in the volume and diversity of foreign-born footballers have, however, remained empirically untested. In this article, we empirically test whether the presence of foreign-born footballers at the World Cup has changed over time in respect to these two dimensions of migration. We conducted an analysis on 4.761 footballers, derived from the fifteen national teams that competed in at least ten editions of the World Cup between 1930 and 2018, which comprises of 301 foreignborn football players. We argue that countries' different histories of migration, in combination with historically used citizenship regimes, largely influence the migratory dimensions of their representative football teams. Our outcomes show that the (absolute) volume of foreign-born footballers in World Cups is indeed increasing over time. Moreover, foreign-born footballers seem to come from an increasingly diverse range of countries. We, therefore, conclude that the World Cup has become more migratory in terms of volume and diversity from an immigration perspective.
\end{abstract}

Keywords: Migration, Citizenship, Nationality, Foreign-born, Diversity, History, Football, FIFA World Cup

\section{Introduction}

At the 2018 Fédération Internationale de Football Association (FIFA) Men's World Cup - hereafter the World Cup - in Russia, 84 football players competed for national teams other than their country of birth; the second highest absolute number of foreign-born footballers in the history of the World Cup, just after the 2014 edition. ${ }^{1}$ At the 2018 World Cup, the national team of Morocco selected the most foreign-born players as three-fourths (seventeen out of twenty-three) of their footballers were born outside Morocco's territorial borders. Interestingly, this African country could even field a European-born squad (Kuper, 2018; Storey, 2019; van Campenhout \& Oonk, 2018). When it comes to national football teams, which (arguably) tend to represent the nation, the presence of foreign-born players seems somewhat paradoxical and

(c) The Author(s). 2019 Open Access This article is distributed under the terms of the Creative Commons Attribution 4.0 International License (http://creativecommons.org/licenses/by/4.0/), which permits unrestricted use, distribution, and reproduction in any medium, provided you give appropriate credit to the original author(s) and the source, provide a link to the Creative Commons license, and indicate if changes were made. 
challenging to the spirits of FIFA's international competitions between, more or less, homogenous (sporting) nations (Bairner, 2001; Holmes \& Storey, 2011; Keys, 2006).

At present, academic work and media journalists often claim that foreign-born players in national football teams have become more prevalent (Goldblatt, 2014; Maguire \& Pearton, 2000). Seemingly, countries are increasingly represented by players with a 'vague' connection to the countries whose jerseys they wear, which fuels debates on the representativeness of national teams and the belonging to the nation of these foreign-born players. However, systematically gathered numbers to support and historically legitimize claims about the World Cup becoming more migratory over time are lacking, even at FIFA. The question therefore is whether the claims that national football teams increasingly include foreign-born footballers is legitimate. So far, such claims have only been empirically tested for the Olympics, leading Jansen and Engbersen to conclude that 'the Olympic Games indeed have not become inherently more migratory' throughout its history (Jansen \& Engbersen, 2017, p. 1). The absence of similar research on national football teams is surprising as it is especially in the realm of international football - with the World Cup as a key example - that migratory processes are well documented, visible to the public, and (sometimes) fiercely debated in the media and by the general public (Holmes \& Storey, 2011; Lanfranchi \& Taylor, 2001; Maguire \& Falcous, 2011). The purpose of this paper is to create some historical clarity on the volume and diversity of foreign-born footballers in national teams throughout the history of the World Cup, c. 1930-2018. To answer the question whether the FIFA World Cup has become more migratory, we will analyse the squads of a selected number of national football teams that competed at the World Cups between 1930 and 2018. We will relate our findings to trends in international migration, national (im)migration histories and citizenship regimes of the selected countries to gain more insight in the processes of this specific, often overlooked, form of migration.

The first part of this article outlines a conceptual framework, which is based on studies in the fields of international migration, sports history and sociological work on football. Based on broader patterns and trends in international migration, a classification on national migration histories is given and related to general citizenship regimes. We later use this classification to explain changes in the volume and diversity of foreign-born players throughout the history of the World Cup and within national football teams. In the second part, we clarify the setup of our dataset, and explain the conceptualisation and analysis of (developments in) the volume and diversity of foreign-born footballers. Part three consists of our empirical findings where we present the volume and diversity of foreign-born football players in the World Cups over time and relate our outcomes to the theoretical framework as presented in part one. We conclude by answering whether the World Cup has become more migratory throughout its history.

\section{(Im)migration histories}

It could be argued that international migration, being a central dynamic within globalisation, has increased because of the (relative) openness of national borders (Carens, 2013; Castels, de Haas, \& Miller, 2014, p. 5). Trends in international migration show that, despite a clear increase in the absolute number of international migrants throughout the 19th, 20th and the twenty-first century, the relative number of people migrating has remained fairly stable; between the 2 and $4 \%$ of the world population (Czaika \& de 
Haas, 2014; Zlotnik, 1999). However, great differences between regions in the world exist, and migration does not happen everywhere at the same speed or in isolation from other global processes (Castels et al., 2014). Perhaps contradictory to the popular image of refugees and asylum seekers, migrants are increasingly highly skilled which makes them globally employable. It is, in particular, the mobility of this elite group of migrants - existing of IT-workers, academics, diplomats, health workers and professional athletes like football players - that has increased in intensity and composition (Kerr, Kerr, Özden, \& Parsons, 2016).

As not all countries have witnessed similar processes of migration within the same timeframes, differences in countries' histories of migration have arisen (Castels et al., 2014, p. 13-14; Czaika \& de Haas, 2014; Flahaux \& de Haas, 2016). During the late 19th and early 20th centuries, the Americas (North and South) encountered 'waves of immigrants' of which the vast majority hailed from (continental) Europe (Goebel, 2016; Pew Research Center, 2015). After this period of transatlantic migration, international migration decreased worldwide as a consequence of upcoming ideologies of nationalism, and the implementation of stricter national policies on immigration and naturalisation (Castels et al., 2014). After the Second World War, most notably since the 1960s, international migration expanded (again). From then onwards, three types of migration histories can be distinguished based on countries' historical trends in immigration; countries of immigration, latecomers to immigration, and nations of immigrants (Czaika \& de Haas, 2014; Hollifield, Martin, \& Orrenius, 2014).

First, most West European countries - like Belgium, England, France, Germany, the Netherlands, Sweden and Switzerland - are considered 'countries of immigration'; despite the fact that the countries themselves may see this differently (Hollifield et al., 2014, p. 13). While most of these countries have witnessed periods of emigration before the 1960s, the flow of migrants turned due to overall improvements in the living conditions within these countries, processes of decolonisation, and changes in national policies and ideologies around immigration, with the active recruitment of 'guest workers' as a prime example (Flahaux \& de Haas, 2016). Second, countries like Italy and Spain, but also South Korea, have for a long time been exporters of migrants. It was only during the last decades of the twentieth century that these countries 'made the transition from countries of emigration to countries of net immigration' (Hollifield et al., 2014, p. 20). It is therefore that these countries are classified as 'latecomers to immigration'. Third, the (ongoing) attractiveness of traditional countries of settlement, like the United States, Canada, Australia and New Zealand, has classified them as 'nations of immigrants' (Czaika \& de Haas, 2014; Hollifield et al., 2014). It is because of their, generally, open attitude towards foreigners that immigrants have become an active part of their historical consciousness and national identity. Moreover, the diversity of 'their current people are the result of histories of large-scale immigration' (Castels et al., 2014, p. 14). This, however, by no means mean that the countries within this category have always had welcoming immigration- and naturalization policies. These countries also witnessed fluctuations in the openness of their national policies and ideologies towards immigrants, let alone that immigrants could apply for citizenship in one of these countries (Hollifield et al., 2014).

Following Jansen and Engbersen (2017, p. 3), we add a fourth category to the classification of Hollifield et al., (2014) to deal with the migration histories of countries like 
Argentina, Brazil, Mexico and Uruguay; 'former countries of immigration'. Before and during the 1960s, the South American continent was one of the top immigration destinations, especially for (Southern) Europeans (Goebel, 2016). Over time, however, these countries witnessed a reversed trend of the earlier mentioned 'latecomers to immigration'. Immigration to these South American countries has gradually reduced and seems to be replaced by an outflow of people, predominantly towards 'countries of immigration' and 'nations of immigrants'.

Within the process of classifying countries based on their migration histories, it was highlighted that the intensity and direction of international migration has historically been subjected to change. Based on the outlined (im)migration histories, we wonder whether these patterns in immigration are reflected in the selections of national football teams throughout the history of the World Cup. We expect that foreign-born footballers have been historically present within the national football teams of 'nations of immigrants', while an increase in the volume and diversity of foreign-born players is expected within representative teams of 'countries of immigration' after the 1960s.

\section{Citizenship regimes and FIFA's eligibility regulations}

Historically, citizenship as status - the legal entitlement to membership of a country is ascribed to an individual at birth through either one of the two birthright principles: (1) jus soli (literally, the right of the soil), which grants citizenship on the basis of birth within a state's territory, and (2) jus sanguinis (literally, right of blood), which grants citizenship on the basis of descent from a citizen like (grand-) parents. Whereas citizenship of the United States is mainly acquired by being born within the United States or in areas under its jurisdiction, German citizenship is chiefly acquired through parental heritage. Children born outside of Germany to a German parent(s) are therefore eligible to German citizenship (Bosniak, 2006; Brubaker, 1992; Joppke, 2010; Shachar, 2009). There is, however, a 'clear process of convergence between countries with jus soli and jus sanguinis traditions', meaning that most (West-European) countries nowadays grant citizenship along both policies - under national specific conditions (Vink \& De Groot, 2010). In addition to these birthright principles, citizenship can also be acquired later in life through naturalisation which mainly happens by marrying a native citizen (jus matrimonii) or establishing residence in a country (jus domicilii). Naturalisations are often preceded by specific conditions like a minimum of years residing in a country, an income criterion or a proof of language proficiency. ${ }^{3}$ The naturalisation conditions people need to meet to acquire citizenship however differs, and historically has differed, per country - and changed within countries over time which has created a global imbalance in terms of citizenship opportunities for migrants (Jansen, Oonk, \& Engbersen, 2018; Vink \& De Groot, 2010).

Even though it was quite common for footballers to represent other countries than their native one until the mid-1960s - famous examples are Argentina-born Alfredo Di Stéfano who played for Argentina and Spain, and the Hungarian Ferenc Puskás who represented Hungary and Spain - this (slowly) changed from 1962 onwards when FIFA introduced their eligibility regulations. These regulations needed to ensure that national football teams would remain a symbol of nationalism (Hall, 2012). Its ground rule states: 'any person holding a permanent nationality that is not dependent on residence in a certain country is eligible to play for the representative teams of the association of 
that country' (FIFA, 2016, p. 70). In 2004, as a reaction on the growing tendency of players with dual nationality in national teams, FIFA implemented additional rulings to eligibility that obliged a 'clear connection' between footballers and the country they represented (Hall, 2012, p. 195). ${ }^{4}$ Despite these additional rulings, football players' connection with the national team they represent seems to be more and more based on ((great) grand-) parental heritage, their years of loyalty to a football club in a national league (residency) or through marriage, instead of being based on their place of birth (Holmes \& Storey, 2011). Some authors even argue that we are witnessing a 'marketization of citizenship' because of the increasing involvement of national governments in granting (fast-tracked) citizenship to talented athletes, amongst them footballers (Shachar, 2011; Shachar \& Hirschl, 2014).

Although FIFA determines who under which conditions is eligible to compete in international football, they do not have a say in national citizenship procedures. National governments remain the only institutions that can legally grant citizenship to individuals (Hall, 2012; Holmes \& Storey, 2011). The migration histories of countries, with their differences and over time changes in national citizenship policies, therefore have an influence on the volume and diversity of foreign-born players within the selected national teams and, as a consequence, at the World Cup.

\section{Methodology}

While transfers of football players in club football are (historically) careful watched and documented by official institutions and the media, accurate numbers on foreign-born footballers in national football teams are lacking, especially before the mid-1960s (Hafner, 2014). FIFA only then started to - little by little - keep track of footballers' movements between national teams (Hall, 2012). To overcome this lack, we created a database consisting of all footballers who represented a national team at the World Cup between 1930 and 2018. This resulted in a database of 10.137 footballers, of which 996 are classified as foreign-born (van Campenhout, van Sterkenburg, \& Oonk, 2019). The database comprises of football players' biographic data in terms of the country they represented as an international, their date of birth, and their place- and country of birth, as a combination of these data can indicate international movements (Özden, Parsons, Schiff, \& Walmsley, 2011). Moreover, it includes the nationalities of parents and grandparents which makes it possible to trace a football player's eligibility for a national football team

along his bloodline. ${ }^{5}$ However, even with these detailed biographic data listed, it remains hard to measure this specific type of migration since the 'reason, timing and nature of an athlete's move' remains uncertain (Horowitz \& McDaniel, 2015, p. 39). It is therefore that most studies on international migration rely on foreign-born data (Dumont \& Lemaitre, 2005; Özden et al., 2011). In the current study we will do the same but we are aware that it has its limitations and we have reflected on those limitations in an earlier article (van Campenhout et al., 2019). Further, as each state determines and alters its citizenship conditions, different acquisition possibilities of citizenship have emerged within countries. Because of this, a diversity within the foreign-born population of countries has come into existence over time (Castels et al., 2014). It, however, lies beyond the scope of this article to discuss different typologies of foreign-born players in-depth.

For this article, we created a dataset from our database based on fifteen national teams which resulted in a dataset of 4.761 football players - 301 of them are classified 
as foreign-born - who form the basis for the analysis. ${ }^{6}$ The fifteen national teams selected are (in alphabetical order) Argentina, Belgium, Brazil, England, France, Germany, Italy, Mexico, Netherlands, South Korea, Spain, Sweden, Switzerland, United States, and Uruguay. The motivation for this selection is threefold:

1. The selected countries have different histories of migration and cover the distinction between 'countries of immigration' (Belgium, England, France, Germany, the Netherlands, Sweden, and Switzerland), 'latecomers to immigration' (Italy, South Korea, and Spain), 'nations of immigrants' (United States), and 'former countries of immigration' (Argentina, Brazil, Mexico, and Uruguay).

2. The selected countries employ - and have employed - different national policies around citizenship and naturalisation, either based on jus soli or jus sanguinis (or a combination).

3. The selected countries qualified at least ten times for the World Cup. While this criterion provides us with some historical continuity in terms of contenders, it unconsciously leads to a focus on (football's) global centres as most of the selected national teams originate from Europe and South America.

The presence of foreign-born players in national football teams is described in terms of volume, referring to the absolute number of football players that competed for another national team than their native country at the editions of the World Cup (1930-2018). Besides the absolute numbers of players, we also mapped the relative numbers of foreign-born footballers which means the percentage of foreign-born players within the selections of the selected national teams and at the editions of the World Cup. The distinction between absolute and relative numbers is relevant since it is only possible to speak of a growing intensity of foreign-born footballers in national football teams over time when they are taken as a relative share of the 'other' players at the editions of the World Cup and within the selections of national teams (population) (Czaika \& de Haas, 2014). Further, in 156 of the 4.761 cases (just over 3\%), information on the exact birth place of football players is missing. However, their country of birth is known and traceable. Moreover, as the vast majority of footballers has represented their country of birth throughout the history of the Word Cup, these 156 football players are considered as 'nationals' (Dumont \& Lemaître, 2005).

With diversity we focus on what Czaika and de Haas (2014) call 'immigration diversification'; assuming that foreign-born footballers have come from 'an increasingly geographically distant and diverse array of origin countries' (p. 291). We take on a 'destination country perspective' to highlight diversifying immigration patterns of foreign-born footballers within our selection. To measure the diversity among foreign-born football players we, like other social scientists, use the Herfindahl-Hirschmann-index (HHI). The HHI calculates 'the sum of squares of the proportion of each immigrant population (IMi) as a share of the total immigrant population $(M)^{\prime}$ : Diversity $(\mathrm{D})=1-\sum_{i=1}\left(\frac{I M \mathrm{i}}{M}\right)^{2}$ (Jansen \& Engbersen, 2017, p. 7). Generally, diversity-values lie between 0 and 1 , whereby higher values indicate that football players' countries of birth are, within the selection of a national team, relatively 'scattered' and therefore more diverse (Czaika \& de Haas, 2014). Within our selection, most $\mathrm{D}$-values are however exact 0 or 1 . This means that either national teams do not 
have selected any foreign-born players (1) - all footballers are born in the country they represent - or, in the case of 0 , that foreign-born footballer(s) in a national team originate from a single other country. We calculated the D-values of foreign-born footballers for three World Cup editions: 1934, 1962 and 2014. ${ }^{7}$ We selected these editions because (i) they are spread out over a long time and, therefore, might illustrate how diversity in terms of players' country of origin has developed over time; either remaining (fairly) stable or changing substantially (Lanfranchi \& Taylor, 2001; Taylor, 2006), and (ii) it allows us to compare the football-related diversity outcomes with changes in the diversification of immigration in general and to the typologies of (im)migration histories (Czaika \& de Haas, 2014; Jansen \& Engbersen, 2017).

\section{Has the World Cup become more migratory?}

In this section we present the results of our empirical analysis. We will start by showing the historical changes in the volume of foreign-born footballers throughout the history of the World Cup (1930-2018). Based on these insights, we discuss the diversity of foreign-born players in terms of their countries of origin within their representative national teams at three World Cup editions: 1934, 1962 and 2014.

\section{Increased numbers of foreign-born footballers}

In general, it can be stated that the World Cup has become more migratory throughout its history. Although Table 1 shows an ebb and flow-pattern in the volume of foreign-born players throughout the history of the World Cup, the overall trend in the number of foreign-born footballers seems to be upwards for our selection of national teams, especially since the mid-1990s. With an average of just over $6 \%$, the volume of foreign-born footballers at the World Cup seems to be notably higher than the more steadily increasing trends in international migration; which historically oscillates between the 2 and 4\% (Czaika \& de Haas, 2014; Zlotnik, 1999).

Based on the wavy line that represents the volume of foreign-born players throughout the history of the World Cup (Table 1), three periods of (im)migration can be distinguished. First, during the earliest editions of the World Cup (1930-1938) it was not uncommon for footballers to represent another national team than their country of birth as the percentages above $7.5 \%$ indicate. With more than $16 \%$ of the footballers being foreign-born, the 1938 World Cup stands out. This outlier can be explained by the presence of nine Austrian-born footballers in the selection of the German Empire. These nine players were, however, forced to represent Germany instead of their country of birth due to Austria's Anschluss to Hitler's German Empire just three months before the start of the 1938 World Cup. ${ }^{8}$ Because of these 'overnight' changes in territory and jurisdiction, the national team of Austria was retracted from this edition of the World Cup, leaving the Austrian footballers with basically no other option than to play for Germany. Second, after World War II, the number of foreign-born players at the World Cup reduced to an average around 6\% in the period between 1950 and 1962. This flattening of the numbers can be seen as a consequence of the interwar period which was characterised by a reduction of international labour migration 'partly because of economic stagnation and crisis, and partly because of increased hostility towards immigrants in many countries' (Castels et al., 2014, p. 96). Moreover, it was in 1962 that FIFA introduced their eligibility criteria which restricted players' freedom of 
Table 1 Absolute and relative numbers of foreign-born football players within the fifteen selected national teams per World Cup, 1930-2018

\begin{tabular}{|c|c|c|c|}
\hline World Cup & Total \# of Footballers & \# Foreign-born Footballers & $\%$ Foreign-born Footballers \\
\hline 1930 & 131 & 11 & $8,40 \%$ \\
\hline 1934 & 233 & 19 & $8,15 \%$ \\
\hline 1938 & 176 & 29 & $16,48 \%$ \\
\hline \multicolumn{4}{|l|}{1942} \\
\hline \multicolumn{4}{|l|}{1946} \\
\hline 1950 & 194 & 11 & $5,67 \%$ \\
\hline 1954 & 218 & 16 & $7,34 \%$ \\
\hline 1958 & 154 & 4 & $2,60 \%$ \\
\hline 1962 & 198 & 11 & $5,56 \%$ \\
\hline 1966 & 220 & 5 & $2,27 \%$ \\
\hline 1970 & 176 & 4 & $2,27 \%$ \\
\hline 1974 & 154 & 2 & $1,30 \%$ \\
\hline 1978 & 198 & 6 & $3,03 \%$ \\
\hline 1982 & 176 & 9 & $5,11 \%$ \\
\hline 1986 & 242 & 6 & $2,48 \%$ \\
\hline 1990 & 266 & 10 & $3,76 \%$ \\
\hline 1994 & 264 & 14 & $5,30 \%$ \\
\hline 1998 & 264 & 25 & $9,47 \%$ \\
\hline 2002 & 299 & 26 & $8,70 \%$ \\
\hline 2006 & 299 & 26 & $8,70 \%$ \\
\hline 2010 & 299 & 22 & $7,36 \%$ \\
\hline 2014 & 322 & 27 & $8,39 \%$ \\
\hline 2018 & 278 & 18 & $6,47 \%$ \\
\hline Totals & 4761 & 301 & $6,32 \%$ \\
\hline
\end{tabular}

[Due to the Second World War there were no World Cups held in 1942 and 1946]

Source: G. van Campenhout

choice in national teams (Hall, 2012; Holmes \& Storey, 2011). Although these regulations were mainly an acknowledgement of what was already happening in international football, these regulations have arguably contributed to a further decrease in the number of foreign-born players at the World Cup; to a maximum of $3 \%$ in the editions afterwards. It was not until the 1980s that the volume of foreign-born footballers curled back towards similar levels as on the morrow of the Second World War. Thirdly, an (steady) increase in the number of foreign-born players at the World Cup can be seen since the mid- to late-1990s onwards. Where the relative share of foreign-born footballers between the editions of 1994 and 1998 almost doubled - from nearly 6\% in 1994 to more than $10 \%$ in 1998 - thereafter the percentages of foreign-born footballers, usually, continues to be above the $8 \%$. This upward trend is in line with liberalisation processes that relaxed citizenship regimes since the 1980s and seems to resemble migratory patterns in the Olympics (Jansen et al., 2018; Jansen \& Engbersen, 2017). Interestingly, with nearly 6,5\%, the 2018 World Cup shows a slight decrease in the percentage of foreign-born players, where we would have expected a further growth in the number of foreign-born footballers in the selected national teams based on 
international migration patterns. Overall, the relative number of foreign-born footballers in the recent decades seems to, more or less, stabilise around heightened migration percentages, fluctuating between the 6,5 and $9 \%$.

When relating the volume of foreign-born footballers to the countries' histories of migration, it is rather obvious that 'countries of immigration' have historically selected foreign-born players as they have received a fair amount of immigrants over time (Castels et al., 2014; Hollifield et al., 2014). There are, however, considerable differences in the presence of foreign-born players between national teams within this classification, which mainly arise from differences in historically used citizenship regimes (Brubaker, 1992). Although France and Sweden, for example, fall into the same category of migration histories - with immigration percentages of over $10 \%$ since the mid-1990s - the national team of France has selected far more foreign-born players (62) than Sweden did (2) (Table 2). Where France, on the one hand, has a colonial history, and historically French citizenship could be acquired by people based on jus soli, it has been able to compose the selection of its national football team out of (foreign-born) players from a territorial large pool of talent - just like other former colonial empires such as England and the Netherlands (Dubois, 2010; Taylor, 2006). Sweden, on the other hand, lacks a colonial history and, in addition, Swedish nationality is historically granted through descent (jus sanguinis). In addition to this, many citizenship regimes in West European countries have opened up to foreigners around the 2000s. For foreigners,

Table 2 Numbers of foreign-born footballers per selected national team at the FIFA World Cup (1930-2108)

\begin{tabular}{|c|c|c|c|}
\hline National football team & \# Selected footballers & \# Foreign-born footballers & $\%$ Foreign-born footballers \\
\hline \multicolumn{4}{|l|}{ Nations of Immigrants } \\
\hline United States of America & 212 & 48 & $22,64 \%$ \\
\hline \multicolumn{4}{|l|}{ Countries of Immigration } \\
\hline Belgium & 283 & 10 & $3,53 \%$ \\
\hline England & 335 & 11 & $3,28 \%^{a}$ \\
\hline France & 329 & 62 & $18,84 \%$ \\
\hline Germany & 423 & 55 & $13,00 \%^{b}$ \\
\hline The Netherlands & 223 & 16 & $7,17 \%$ \\
\hline Sweden & 267 & 2 & $0,75 \%$ \\
\hline Switzerland & 246 & 35 & $14,23 \%$ \\
\hline \multicolumn{4}{|l|}{ Latecomers to Immigration } \\
\hline Italy & 400 & 20 & $5,00 \%$ \\
\hline Spain & 335 & 15 & $4,48 \%$ \\
\hline South Korea & 223 & 7 & $3,14 \%$ \\
\hline \multicolumn{4}{|c|}{ Former Countries of Immigration } \\
\hline Argentina & 377 & 5 & $1,33 \%$ \\
\hline Brazil & 465 & 0 & $0,00 \%$ \\
\hline Mexico & 353 & 10 & $2,83 \%$ \\
\hline Uruguay & 290 & 6 & $2,07 \%$ \\
\hline
\end{tabular}

Source: G. van Campenhout

${ }^{a}$ England's percentage of foreign-born footballers is rather low, when compared with France, which partly derives from differences in citizenship regimes

${ }^{\mathrm{b}}$ In the case of foreign-born footballers in the national team of Germany, the Federal Republic of Germany (West-Germany) is taken as its forerunner. Players born in East-Germany are considerd foreign-born which, partly, explains Germany's high percentage of foreign-born footballers 
amongst them footballers, it became easier - or even possible at all - to apply for citizenship based on either territorial considerations (jus soli), affiliation (jus sanguinis), or through naturalisation (jus domicilii or jus matrimonii) (Vink \& De Groot, 2010). Further, from the 1960s onwards, economic developments in Western Europe turned most former countries of emigrants into 'countries of immigration'. In many West European countries, the recruitment of foreign labour led to clear increases in migrants within their population. While these guest workers were expected to return to their home countries after some time they were, as a consequence of the liberalisation of national citizenship regimes, legally allowed to apply for citizenship within many European countries (Jansen et al., 2018). These demographic changes became in particular notable in the national football teams of these countries when the children of these migrants were selected. The 2014 national team of Switzerland is a key example in this respect with $65 \%$ of their selected players having migratory roots (Afonso, 2004). In a similar vein, the qualification for the World Cup of one of the 'nations of immigrants', especially the United States, instantly heightens the volume of foreign-born footballers at that specific edition. As 'immigration is part of the founding national ideal', the selection of foreign-born players for the U.S. men's teams has a long history (Hollifield et al., 2014). With nearly $23 \%$, the average share of foreign-born players in the US national team even exceeds their national immigration number (Table 2) (Pew Research Center, 2015; United Nations, 2017).

The European 'latecomers to immigration', Italy and Spain, have historically selected a small number of foreign-born players; generally, one or two per World Cup edition for which they qualified. Interestingly, most of their foreign-born players originate from South American countries, especially from Argentina and Brazil. Moreover, as the citizenship regimes of Italy and Spain are based on jus sanguinis, footballers born on the South American continent in families with Italian or Spanish roots can (relatively easy) acquire citizenship of these countries which, in addition, makes them eligible to play for its representative national team. In particular within the national team of Italy, Argentina-born players seem to be omnipresent throughout its history with Luis Felipe Monti (1934), Humberto Maschio (1962) and Mauro Camoranesi (2014) as some examples (Foot, 2006; Martin, 2004). South Korea, another 'latecomer to immigration', has only selected a couple of foreign-born players throughout its World Cup history. As the South Korean government places a high value on the ethnic and cultural homogeneity of its population it is hard for foreigners to acquire Korean citizenship through naturalisation. The Korean government, however, has made its naturalisation processes more flexible since 2011, especially for highly skilled migrants like talented athletes (Choi, 2018). Frankfurt-born Cha Du-ri, within a Korean family, is up to now the only foreign-born footballer who represented South Korea at the World Cup. The other five foreign-born players that represented South Korea (in the 1954 World Cup) were born in North Korea. Despite the changing (political) opinions on immigrants in Korea, the selection of foreign-born players in South Korea's national football team is still unique (Choi, 2018).

In contrast to the 'latecomers to immigration', mainly South American countries quite recently experienced a change in the flows of migration; from immigration towards emigration (Goebel, 2016). Within the national teams of Argentina, Brazil, Mexico and Uruguay, an effect of this 'curling over' is, however, barely recognisable. Two reasons for the failing of this effect can be distinguished. First, these countries have just recently 
transformed into 'countries of emigration', meaning that their diaspora is not large in numbers (yet). The chances of recruiting from a pool of foreign-born footballers, who are eligible due to filiation, is therefore, small. Mexico, however, is the exception as it historically has been dealing with a net emigration, in particular to the United States. They have just recently started to employ this method of selecting their representative footballers (Helms, 2018; Pew Research Center, 2015). Second, besides nationalist sentiments on national football teams, the low numbers of foreign-born players reflect the stereotyped image of the exceptional football skills of South American footballers (de Vasconcellos Ribeiro \& Dimeo, 2009). Argentina and Uruguay, for example, both selected one Spanish-born player in 1930, and their 2010, 2014 and 2018 squads only included one foreign-born player. ${ }^{9}$ Within the intermediate World Cups, the total number of foreign-born players selected by Argentina and Uruguay remained limited to a maximum of two. In addition, five times world champion Brazil has never selected a foreign-born player in any of their twenty-one World Cup squads.

\section{Immigration diversification in national teams}

Table 3 represents the diversity values of the selected national teams that participated at the World Cup editions of 1934, 1962 and 2014. An overall impression indicates that, from an immigration perspective, the World Cup has diversified throughout its history. For the selected World Cups, the average D-value increased from 0.881 in 1934 to 0.930 in 2014; an increase of more than $5 \%$ in terms of players' countries of origin. This over time increase in diversity reflects wider trends in international migration (Castels et al., 2014; Czaika \& de Haas, 2014; Jansen \& Engbersen, 2017). It is in this respect interesting that, with 0.800 , the $\mathrm{D}$-value for the 1962 edition lies below the one of 1934. This dip can mainly be explained by the implementation of more restrictive citizenship regimes, in particular in 'countries of immigration' and 'nations of

Table 3 Diversity amongst foreign-born football players in the selected national teams

\begin{tabular}{llll}
\hline & $1934(n=19)$ & $1962(n=11)$ & $2014(n=27)$ \\
\hline Argentina & 0.000 & 1.000 & 0.000 \\
Belgium & 1.000 & $N Q$ & 0.000 \\
Brazil & 1.000 & 1.000 & 1.000 \\
England & $N Q$ & 1.000 & 0.000 \\
France & 0.625 & $N Q$ & 0.500 \\
Germany & 1.000 & 0.000 & 0.444 \\
Italy & 0.320 & 0.500 & 0.500 \\
Mexico & $N Q$ & 1.000 & 0.000 \\
Netherlands & 0.000 & $N Q$ & 0.667 \\
South Korea & $N Q$ & $N Q$ & 1.000 \\
Spain & 0.000 & 0.750 & 0.000 \\
Sweden & 1.000 & $N Q$ & $N Q$ \\
Switzerland & 1.000 & 0.000 & 0.500 \\
United States & 0.735 & $N Q$ & 0.560 \\
Uruguay & $N Q$ & 1.000 & 0.000 \\
All 15 Countries & 0.881 & 0.800 & 0.930 \\
\hline Source G. van Campen
\end{tabular}

Source: G. van Campenhout NQ: Not qualified for World Cup edition 
immigrants', in the aftermath of the Second World War (Castels et al., 2014). In addition, international football - like other forms of international sports - increasingly became a symbolic marker of nationalism whereby the selection of foreign-born players did not square well with that discourse (Bairner, 2001; Holmes \& Storey, 2011). This is despite the fact that the selection of some foreign-born players was perfectly in line with national citizenship regimes based on jus sanguinis and, additionally, met the eligibility regulations of FIFA (Jansen et al., 2018).

The arrows in Fig. 1 display the movements of foreign-born players from, on the left side, their country of origin to their adopted, representative national team, on the right side, per selected World Cup. The tale on each arrow represents the absolute number of (foreign-born) footballers that 'moved' between the interlinked countries. Comparing the flows of foreign-born footballers over these three editions indicates the involvement of a wider range of countries of origin in this specific form of migration; 11 countries of origin in 1934, 7 in 1962, and 17 in 2014. ${ }^{10}$ This immigration diversification of national teams seems to match the general tendencies of the globalisation of migration as 'immigration countries tend to receive migrants from an increasingly diverse array of source countries' (Castels et al., 2014, p. 16).

Nuancing these general observations on the increased diversification of foreign-born footballers, based on the different histories of migration, indicates the importance of 'nations of immigrants' like the United States in this respect. Looking at the countries from which the foreign-born players in the US teams of 1934 and 2014 originate, the pattern seems rather scattered including countries of origin all across Europe, like England, Scotland, Germany, Norway and Sweden (Fig. 1). If we, however, focus on the foreign-born players that moved towards national teams within the categories of 'countries of immigration' or 'latecomers to immigration', these movements seem to be more in line with established networks of migration of their adopted countries. In most cases, foreign-born footballers compete for countries that are historically connected to their country of birth such as former colonies, befriended states or neighbouring countries. This mainly happens because these countries have a certain degree of cultural similarity and because their better chances of acquiring citizenship (Holmes \& Storey, 2011; Taylor, 2006). In other words, the countries of origin of foreign-born players in national football teams are not random or part of a free market of choice but are often guided, or constrained, by colonial relations, specific migration histories, local and international legislation, and national traditions. For example, the (ethnic) diversity within the 1998 national team of France is often considered a vivid memory of its (colonial) migration history (Dubois, 2010; Storey, 2019).

The importance of established migration networks for foreign-born footballers can also be highlighted when focussing on the 'countries of origin' of foreign-born players who represented Italy. At the World Cups of 1934, 1962 and 2014, eleven out of the combined total of fourteen foreign-born footballers in the Italian team originated from Argentina or Brazil (nearly $80 \%$ of the number of foreign-born players). This high share of South American born football players competing for Italy is, as mentioned above, closely related to the emigration waves from Italy towards South America in the late 19th and early 20th centuries (Goebel, 2016). Moreover, these South American competitions had, around the mid-1920s, no shortage of high-class footballers with Italian roots (Martin, 2004). To be able to exploit this pool of talent, the Italian government 


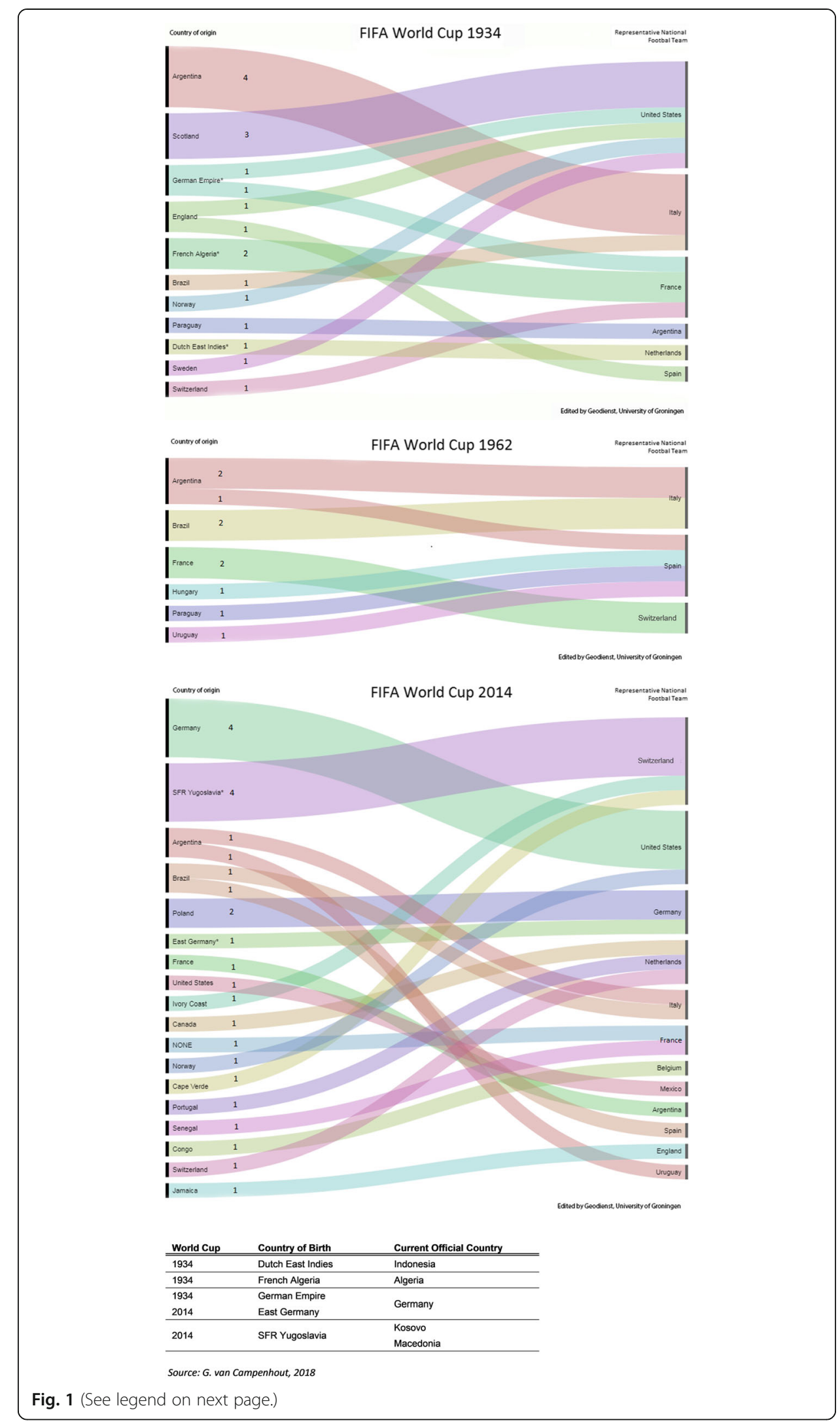


(See figure on previous page.)

Fig. 1 Immigration diversification of the selected national teams at the 1934, 1962 and 2014 World Cup. The strokes in this figure display the movements of foreign-born players from, on the left side, their country of origin to their adopted national team, on the right side, for the three World Cup editions. The number displayed on the lines, near the countries of birth, represent the absolute numbers of football players that moved between the countries for that specific edition of the World Cup. Moreover, the thicker a stroke, the more football players have moved from a particular country of birth. A stroke's colour relates to a country of birth which, within a single edition of the World Cup, can be followed to the national teams that selected foreign-born players. Because territorial borders have changed over time, a small table is added to this figure to illustrate the relevant border changes that have occurred throughout the history of the World Cup

introduced a joint citizenship in the mid-1920s which legally made 'the sons of Italians born abroad [to be] considered Italians' (Martin, 2004, p. 195, brackets added). The Italian government considered these players 'Italians abroad' as they 'had Italian 'blood', Italian surnames and Italian relatives' (Foot, 2006, p. 427). Moreover, as these Argentina-born Italians were immediately eligible to play for the national team upon receiving Italian citizenship, it was not uncommon for the Italian football federation to select the best football players from their South American diaspora.

Clearly, foreign-born footballers originate from an increasingly diverse pool of countries which matches the so-called globalisation of migration (Castels et al., 2014, p. 16). However, as the majority of these movements seems to be guided by historical power relations between countries, the immigration diversification remains rather limited. The true diversification of foreign-born footballers in terms of 'countries of origin' is mainly related to 'nations of immigrants', such as the United States.

\section{Conclusion and discussion}

In this paper, we provided a historical overview on the rising intensity and diversity of foreign-born footballers in the selections of fifteen national teams at the World Cup (1930-2018). To support claims on the World Cup becoming more migratory over time, we based our argumentation on a complete dataset, from fifteen selected countries, that consist of 4.761 football players of which 301 were classified as foreign-born. Our outcomes, first, indicate that the presence of foreign-born players in national football teams is nothing new as even in the 1930s players born abroad represented other countries. Second, foreign-born footballers are increasingly representing other national teams instead of the one of their country of birth. And third, the countries of origin of foreign-born footballers have diversified over time. We, therefore, conclude that the World Cup has become more migratory throughout its history.

When contextualising our data, we observed ebb and flow movements within the volume of foreign-born footballers at the World Cup. In recent decades, a clear overall upward trend appears in this volume which reflects broader historical trends in international migration and historical citizenship regimes (Czaika \& de Haas, 2014; Jansen \& Engbersen, 2017). Obviously, differences in the number of foreign-born players exist between (i) the editions of the World Cup and (ii) within national football teams. Whereas the volume of foreign-born footballers at an edition of the World Cup largely depends on the national teams that qualify, differences between national teams in selecting foreign-born footballers mainly comes into existence because of a country's history of migration (Hollifield et al., 2014). Further, from an immigration perspective, 
the developments in the diversity of foreign-born players at the World Cup basically reflects general tendencies of a globalisation of migration; foreign-born footballers seem to originate from a wider, more diverse, range of countries in the latest editions (Castels et al., 2014). Although the diversification of 'countries of origin' increases, these 'newly' involved countries are not at random. The flow of foreign-born players between 'countries of origin' and 'representative national team' seems to be limited as the majority of foreign-born footballers represents a country that is part of the established migration network of his country of birth. In other words, the selection of foreign-born players is guided - or restricted - by historical relationship between countries.

As indicate above, it is important to emphasise that not all countries are confronted with the same migratory processes at the same time, and that large differences exist between countries in the world in terms of how citizenship of a country can be acquired (Castels et al., 2014; Czaika \& de Haas, 2014). By distinguishing between 'nations of immigrants', 'countries of immigration,' 'latecomers to immigration', and 'former countries of immigration, we have tried to illustrate how migration histories influence the (increasing) numbers of foreign-born players and diversity within national football teams. We, obviously, did this by means of counting the players who were foreign-born and became naturalised, as possessing citizenship is a prerequisite stated by FIFA. Although it was beyond the scope of this article, our data indicated that most foreign-born footballers were eligible to compete for another national team because they acquired citizenship through descent or because they met the specific naturalisation conditions of a country. These different routes to citizenship, either within and between countries, have unintentionally created a divergence between (naturalised) citizens as the foreign-born can have acquired citizenship upon birth through descent, can be born in another country within an immigrant family and naturalised through jus sanguinis, or moved to a country and naturalised because of jus matrimonii or jus domicilii. According to Yuval-Davis, these 'layers of people's citizenship' surround the 'question of who 'belongs' and who does not, and what are the minimum common grounds - in terms of origin, culture and normative behaviour - that are required to signify belonging' (Yuval-Davis, 2006, p. 207). So, although the foreign-born players in our paper are all legitimately entitled to represent the national team they played for, their selection might have led to (moral) discussions on the representativeness of national football teams as an increase in foreign-born players within the selection of national teams might seem to symbolise a decoupling of citizenship from national identity (Jansen et al., 2018). It would, therefore, be interesting to focus future research on footballers with different types of 'migration backgrounds' in national teams, their representativeness of the country, and which conditions these players have to meet to (morally) 'belong' to the nation they represent on the field.

As each research has its limitations, we want to point out some limitations of our dataset. The framing of our dataset - the selection of fifteen countries and the context of the World Cup - provides a somewhat blurred perspective on the volume and diversity of foreign-born players as they are closely related to the national teams that qualified for the World Cup; an event that only takes place once every four years. It is, therefore, impossible to provide a complete pattern on the development of foreign-born footballers at the World Cup. Further, the amount and quality of available (biographic) data on football players differs greatly per national team and over time. 
There is, obviously, more (detailed) data available on high-profile footballers and on better performing national teams. Moreover, more and more precise data was available on the national teams that participated in the later editions of the World Cup in comparison to the earlier ones. This, obviously, has to do with the increased availability of data on football in general. However, through a thorough search, lots of detailed data on footballers and national teams at the earlier editions of the World Cup have been tracked down. Based on these data, we have been able to produce a reliable image of these historical World Cups.

Yet, despite the limitations of our study in terms of data availability and selectiveness of fifteen national teams, we have been able to generate new insights on global migration patterns in the context of the World Cup. By taking on a comparative historical perspective on foreign-born footballers, we have empirically tested the claim that the World Cup has become more migratory over time.

\section{Endnotes}

${ }^{1}$ Foreign-born footballers are footballers who represent another national team than the country in which they were born. This also involves players who migrated to a country at a very young age. These players are raised, schooled and trained in the country they represent in international football.

${ }^{2}$ Classifying these South American countries as 'former countries of immigration' does by no means mean that they do not witness any form of immigration anymore. Most of these countries, especially certain areas within them, are still dealing with an inflow of immigrants.

${ }^{3}$ Most of the selected countries (see methodology) employ a 5 years residency requirement. Differences between countries exists as, for example, Brazil requires 4 years of residency, people to naturalise to Italian must live there for at least 3 years, while Argentina only has a waiting period of 2 years. For more information, see: http://global cit.eu/acquisition-citizenship/.

${ }^{4}$ FIFA's additional conditions that need to be fulfilled by players to represent more than one country are: 'a) He was born on the territory of the relevant association; b) His biological mother or biological father was born on the territory of the relevant association; c) His grandmother or grandfather was born on the territory of the relevant association; d) He has lived continuously on the territory of the relevant association for at least 2 years' (FIFA, 2016, p. 70).

${ }^{5}$ Nationalities of (grand-) parents were searched for when a player's country of birth differed from the national football team he represented or when (bloodline) connections with other countries were known to the principal researcher.

${ }^{6}$ Not all cases are unique as several footballers have played for the same national team at multiple World Cups.

${ }^{7} 1934$ is chosen to analyse as this was one of the first editions of the World Cup and the numbers of foreign-born footballers at this event was relatively high. The World Cup of 1962 is analysed because of the (re-)expanding of international migration and the introduction of FIFA's eligibility regulations. And the 2014 edition is analysed as it has the highest number of foreign-born footballers within the history of the World Cup and is currently one of the latest editions. 
${ }^{8}$ If these nine Austrian footballers are treated as 'nationals' instead of 'foreign-born', the average share of foreign-born footballers at the 1938 World Cup drops to $10.8 \%$.

${ }^{9}$ Argentina selected France-born striker Gonzalo Higuaín, while Fernando Muslera (born in Argentina) defended Uruguay's goal.

${ }^{10}$ The 'countries of origin' are related to the current political borders, irrespective of the political conditions at the time of the respective World Cup. Moreover, in 2014 there are eighteen sending options if you include the category NONE, which relates to the unique case of Rio Mavuba who was 'born at sea' (see: Fontanini, 2007).

\section{Acknowledgements}

We would like to thank Joost Jansen, Dr. Danyel Reiche and Mel Schickel for their feedback on earlier drafts of this paper. Also we would like to thank Geodienst of the University of Groningen for providing us with the graph displaying the immigration diversification of foreign-born football players (Fig. 1).

\section{Funding}

This study is part of the research project 'Sport and National Identity: Changing Citizenship and the Global Battle for Talent'. The project is funded by Erasmus University Rotterdam via a Research Excellence Initiative (REI) grant.

\section{Availability of data and materials}

To ensure the sustainable archiving and public accessibility of the data on which we have based this paper, we submitted the dataset to the open source research data repository 'Harvard Dataverse'. The data can be accessed via (DOI): https://doi.org/10.7910/DVN/QFWYB4.

\section{Authors' contributions}

GVC gathered the data for this paper and conducted the analyses. JvS and GO provided important additional theoretical insights. The authors jointly participated in writing the paper. All three authors read and approved the final manuscript.

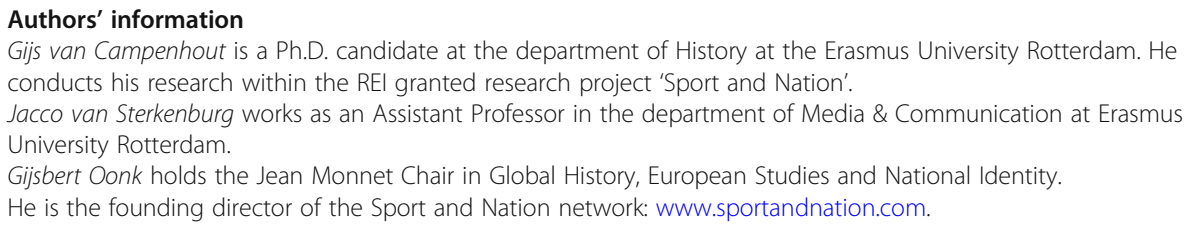

\section{Publisher's Note}

Springer Nature remains neutral with regard to jurisdictional claims in published maps and institutional affiliations.

\section{Author details}

'Department of History, Erasmus School of History, Culture and Communication, Erasmus University Rotterdam, Burgemeester Oudlaan 50, 3062 PA Rotterdam, the Netherlands. ²Department of Media \& Communication, Erasmus School of History, Culture and Communication, Erasmus University Rotterdam, Burgemeester Oudlaan 50, 3062 PA Rotterdam, the Netherlands.

Received: 25 July 2018 Accepted: 28 January 2019

Published online: 17 May 2019

\section{References}

Afonso, A. (2004). Immigration and its impacts in Switzerland. Mediterranean Quarterly, 15(4), 147-166.

Bairner, A. (2001). Sport, nationalism, and globalization. European and North American perspectives, (1st ed., ). Albany: State University of New York Press.

Bosniak, L. (2006). The citizen and the alien. Dilemmas of contemporary membership, (1st ed., ). Princeton and Oxford: Princeton University Press.

Brubaker, R. (1992). Citizenship and nationhood in France and Germany, (2nd ed., ). Cambridge: Harvard University Press.

Carens, J. H. (2013). The ethics of immigration, (1st ed., ). Oxford: Oxford University Press.

Castels, S., de Haas, H., \& Miller, M. J. (2014). The age of migration: International population movements in the modern world, (Fifth ed., ). Houndmills, Basingstoke, Hampshire: Palgrave Macmillan Higher Education.

Choi, Y. (2018). Running for Korea: Rethinking of sport migration and in/flexible citizenship. International Review for the Sociology of Sport, 1-19 https://doi.org/10.1177/1012690218807364.

Czaika, M., \& de Haas, H. (2014). The globalization of migration: Has the world become more migratory? International Migration Review, 48(2), 283-323 https://doi.org/10.1111/imre.12095. 
de Vasconcellos Ribeiro, C. H., \& Dimeo, P. (2009). The experience of migration for Brazilian football players. Sport in Society, 12(6), $725-736$ https://doi.org/10.1080/17430430902944159.

Dubois, L. (2010). Soccer empire: The world cup and the future of France. Berkeley and Los Angeles: University of California Press.

Dumont, J.-C., \& Lemaitre, G. (2005). Counting immigrants and expatriates in OECD countries: a new perspective. In OECD 2004 Annual Report, Trends in International Migration. Retrieved from https://read.oecd-ilibrary.org/social-issuesmigrationhealth/trends-in-international-migration-2004_migr_outlook-2004-en\#ppage1 (1st ed., pp. 116-151).

FIFA (2016). FIFA Statutes. Retrieved from https://resources.fifa.com/image/upload/the-fifa-statutes-in-force-as-of-27-april-20162782908.pdf?cloudid=vga5sv1yxeayptzrdudx.

Flahaux, M.-L., \& de Haas, H. (2016). African migration: Trends, patterns, drivers. Comparative Migration Studies, 4 https://doi.org/10.1186/s40878-015-0015-6.

Fontanini, F. (2007). Q\&A: born on the high seas, footballer finds fame in Europe. UNHCR the UN Refugee Agency. Retrieved from https:/www.unhcr.org/news/latest/2007/11/472b24a04/qa-born-high-seas-footballer-finds-fame-europe.html

Foot, J. (2006). Calcio: A history of Italian football, (1st ed., ). New York: Harper Perennial.

Goebel, M. (2016, May). Immigration and National Identity in Latin America, 1870-1930. In Oxford Research Encyclopedia of Latin American History (pp. 1-20). Retrieved from https://oxfordre.com/latinamericanhistory/view/10.1093/acrefore/ 9780199366439.001.0001/acrefore-9780199366439-e-288.

Goldblatt, D. (2014, June 22). On the pitch the world cup has offered a snapshot of global migration. It's a different story in the stands. The Guardian. Retrieved from https://www.theguardian.com/football/2014/jun/22/world-cup-snapshot-globalmigration-different-stands.

Hafner, Y. (2014, June 23). Blurred nationalities: The list of the "23" and the eligibility rules at the 2014 FIFA world cup [Blog post]. Retrieved from http://www.asser.nl/SportsLaw/Blog/post/blurred-nationalities-the-list-of-the-23-and-the-eligibilityrules-at-the-2014-fifa-world-cup.

Hall, C. D. (2012). Fishing for all-stars in a time of global free agency: Understanding FIFA eligibility rules and the impact on the U.S. Men's National Team. Marquette Sports Law Review, 23(1), 191-209.

Helms, A. (2018, November 13). The man Who's trying to convince some of America's best soccer players to represent Mexico. The Ringer. Retrieved from https:/www.theringer.com/soccer/2018/11/13/18079664/mexico-us-soccer-federationscouting-dual-national-jonathan-gonzalez-efrain-alvarez

Hollifield, J. F., Martin, P. L., \& Orrenius, P. M. (2014). Controlling immigration: A global perspective, (3rd ed., ). Stanford: Stanford University Press.

Holmes, M., \& Storey, D. (2011). Transferring national allegiance: Cultural affinity or flag of convenience? Sport in Society, 14(2), 253-271 https://doi.org/10.1080/17430437.2011.546550.

Horowitz, J., \& McDaniel, S. R. (2015). Investigating the global productivity effects of highly skilled labour migration: How immigrant athletes impact Olympic medal counts. International Journal of Sport Policy and Politics, 7(1), 19-42 https://doi. org/10.1080/19406940.2014.885910.

Jansen, J., \& Engbersen, G. (2017). Have the Olympic games become more migratory? A comparative historical perspective. Comparative Migration Studies, 5. https://doi.org/10.1186/s40878-017-0054-2.

Jansen, J., Oonk, G., \& Engbersen, G. (2018). Nationality swapping in the Olympic field: Towards the marketization of citizenship? Citizenship Studies, 1-18 https://doi.org/10.1080/13621025.2018.1477921.

Joppke, C. (2010). Citizenship and immigration, (1st ed.. ). Cambridge: Polity Press.

Kerr, S. P., Kerr, W., Özden, C.., \& Parsons, C. R. (2016). Global talent flows. Journal of Economic Perspectives, 30(4), 83-106 https://doi.org/10.1257/jep.30.4.83.

Keys, B. J. (2006). Globalizing sport. National Rivalry and international community in the 1930s, (1st ed., ). Cambridge: Harvard University Press.

Kuper, S. (2018, June 1). World cup 2018: Morocco - a team of Europeans. Financial Times, pp. 1-8. Retrieved from https:/www.ft. com/content/ec684d80-6399-11 e8-90c2-9563a0613e56.

Lanfranchi, P., \& Taylor, M. (2001). Moving with the ball. The migration of professional football players, (1st ed., ). Oxford: Berg.

Maguire, J., \& Falcous, M. (2011). Sport and migration. Borders, boundaries and crossings, (1st ed., ). London: Routledge

Maguire, J., \& Pearton, R. (2000). Global sport and the migration patterns of France ' 98 world cup finals players: Some preliminary observations. Soccer \& Society, 1(1), 175-189 https://doi.org/10.1080/14660970008721257.

Martin, S. (2004). Football and fascism. The National Game under Mussolini, (1st ed., ). Oxford: Berg.

Özden, C.., Parsons, C. R., Schiff, M., \& Walmsley, T. L. (2011, February 1). Where on Earth is Everybody? The Evolution of Global Bilateral Migration 1960-2000. The World Bank economic review 25, (1), pp. $12-56$.

Pew Research Center (2015). Modern immigration wave brings 59 million to U.S., driving population growth and change through 2065: Views of Immigration's impact on U.S. society mixed, (pp. 1-127). Washington, D.C.: Pew Research Center.

Shachar, A. (2009). The birthright lottery: Citizenship and global inequality, (1st ed., ). Cambridge: Harvard University Press.

Shachar, A. (2011). Picking winners: Olympic citizenship and the global race for talent. The Yale Law Journal, 120(1), 2088-2139.

Shachar, A., \& Hirschl, R. (2014). On citizenship, states, and markets. The Journal of Political Philosophy, 22(2), 231-257 https:/ doi.org/10.1111/jopp.12034.

Storey, D. (2019). National allegiance and sporting citizenship: Identity choices of 'African' footballers. Sport in Society, 1-13 https://doi.org/10.1080/17430437.2018.1555228.

Taylor, M. (2006). Global players? Football, migration and globalization, c. 1930-2000. Historical Social Research, 31(1), 7-30 http://www.jstor.org/stable/20762099.

United Nations (2017). Trends in International Migrant Stock: The 2017 revision. (United Nations database no. POP/DB/MIG/stock/rev.2017). New York: United Nations, Department of Economic and Social Affairs, Population Division Retrieved from http://www.un.org/en/development/desa/population/migration/data/estimates2/estimates17.shtml.

Van Campenhout, G., \& Oonk, G. (2018). Hyperdiversiteit wordt nieuwe norm WK voetbal [Hyperdiversity becomes the new standard at the World Cup football]. De Volkskrant, p. 23. Retrieved from https://www. volkskrant.nl/columns-opinie/hyperdiversiteit-wordt-nieuwe-norm-wk-voetbal be1ec0d0/. 
Van Campenhout, G., Van Sterkenburg, J., \& Oonk, G. (2019). Who counts as a migrant footballer? A critical reflection and alternative approach to migrant football players in National Teams at the FIFA world cup, c. 1930-2018. The International Journal of the History of Sport. https://doi.org/10.1080/09523367.2019.1581769.

Vink, M., \& de Groot, G. R. (2010). Birthright citizenship, Trends and regulations in Europe. (RSCAS/EUDO-CIT-Comp.; No. 2010/6). EUDO Citizenship Observatory, Robert Schuman Centre for Advanced Studies.

Yuval-Davis, N. (2006). Belonging and the politics of belonging. Patterns of Prejudice, 40(3), 197-214.

Zlotnik, H. (1999). Trends of international migration since 1965: What existing data reveal. International Migration, $37(1), 21-61$

Submit your manuscript to a SpringerOpen ${ }^{\circ}$ journal and benefit from:

- Convenient online submission

- Rigorous peer review

- Open access: articles freely available online

High visibility within the field

- Retaining the copyright to your article 